\title{
Model of Mangrove Ecosystem Utilization as Media and Learning Resources of Environmental Education at Senior High School
}

\author{
Restu \\ Department of Geography, State University of Medan \\ J1. Willem Iskandar Psr V Medan Estate Medan, 20211 Indonesia \\ Corresponding email: restugiran@gmail.com \\ Nurmala Berutu \\ Department of Geography, State University of Medan \\ Jl. Willem Iskandar Psr V Medan Estate Medan, 20211 Indonesia \\ Muhammad Ridha Syafii Damanik \\ Department of Geography, State University of Medan \\ Jl. Willem Iskandar Psr V Medan Estate Medan, 20211 Indonesia \\ Meilinda Suriani Harefa \\ Department of Geography, State University of Medan \\ Jl. Willem Iskandar Psr V Medan Estate Medan, 20211 Indonesia
}

\begin{abstract}
Environmental degradation and natural disasters caused by human activity today continue to increase. The main reason is the low environmental awareness. This indicates the failure of environmental education in schools. Rising levels of public education are not able to raise environmental awareness. The main cause is the integration of environmental educational material on the subject matter that is not supported by the media and appropriate learning resources that failed to establish the competence of graduates. UNIMED have vision and strategic plan for the development of science education. Therefore, the development model of environmental education is very relevant with the vision and the strategic plan. UNIMED received a grant of 60 hectares of mangrove areas in the Percut Sei Tuan District, Deli Serdang Regency to be managed and developed its preservation. The mangrove area is very suitable as media and learning resources of environmental education. However, there is no utilization of mangrove ecosystem models such as the media and learning resources for environmental education in schools. The research objective was to develop a model of mangrove ecosystem utilization as media and learning resources of environmental education. The research method is qualitative descriptive involving school partners in improving the learning model. Design of learning model is to integrate the three subjects of senior high school, ie. Geography, Biology, and Economics. They were packaged in the form of themes that are relevant to the preservation of the mangrove ecosystem. The effectiveness of the model is determined from the model's ability to fulfill basic competence achievement subjects on the curriculum 2013 of Senior High School. The research stages include focus group discussion for analysis of curriculum, syllabus, preparation of integration model, and development of learning tools. The results showed that the mangrove ecosystem can be used as media and learning resources for environmental education at the Senior High School. The model is very relevant to integrate the three
\end{abstract}

subjects of Geography, Biology, and Economics. Based on the curriculum 2013 analysis of senior high school, the basic competencies of relevant subjects can be integrated on Grade 10 for Biology subjects and Grade 11 for Geography and Economics Subjects. The results also showed that the model is very efficient to apply. It can meet the achievements of some basic competence in some subjects so it is easier for teachers to mobilize students to the field and minimize costs.

Keywords-Mangrove Ecosystems, media and learning resources, environmental education

\section{INTRODUCTION}

Environmental education awareness in school is considered less than optimal. It happens due to the environmental is still made as separated knowledge with the other knowledge. Environmental education in school is not be given in specific subjects but integrated with another subject material. Therefore, it can be said that all subjects in the school may include environmental education material integrated with the subject matter at the appropriate basic competencies. It means that every teacher in school requires media and learning resources to support the achievement of environmental education learning outcomes both in the formation of cognitive competence aspect, affective, and psychomotor.

The best media and learning resources for environmental education not only through illustration, video, books, models and verbally by the teacher but also the real environment. Therefore, a natural ecosystem is required to be easily accessible all the time as a media and learning resource for 
environmental education. But in reality, the schools only have limited space largely been used for school building.

The resulted of this research are: (1) curriculum analysis of geography, biology, and economics integrated with environmental education, (2) the effective learning model for senior high school students to improve the environmental competence, and (3) design of integrated implementation lesson using mangrove ecosystem as learning resource plan.

\section{METHOD}

\section{A. Population and Sample}

Population of the research is the whole senior high school partner of UNIMED in Medan and Deli Serdang district as many as 13 schools. Sample selected among the population is 4 schools purposely determined as the schools located closest to the mangrove ecosystem. Those school samples are: MAN 2 Medan, SMAN 1 Percut Sei Tuan, SMAN 11 Medan, and SMAN 7 Medan. Each sample assigns 3 school teachers on the subjects of Geography, Biology and Economics. The determination of the subjects is based on the relevance to environmental education. The number of teachers who serve as research samples are as many as 12 people.

\section{B. Data Collection Techniques and Data Analysis}

Data collection techniques used are observation, questionnaires, and focus group discussions (FGD). Variables used in this research are the relevance among curriculum subjects, learning approaches, the effectiveness of the model, and the efficiency of the model.

The data obtained will be analyzed descriptively so it can illustrate the overall findings of the research that will be presented through narration, displayed frequency tables, pictures, maps and videos.

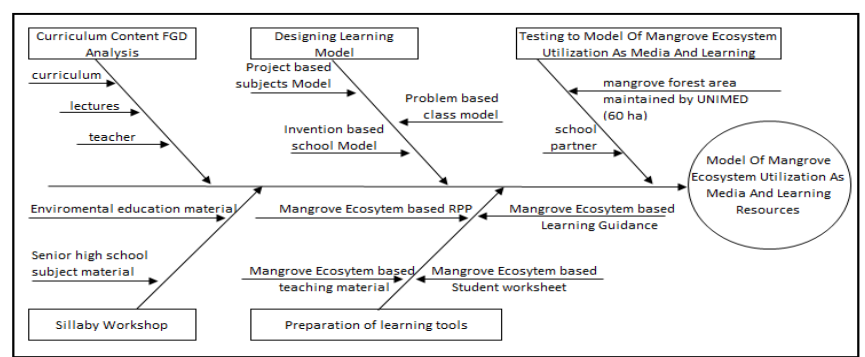

Fig. 1. Based on the initial measurement of the instrument of subjects teachers, the result shows that all teachers have already used the studentcentered learning $\mathrm{m}$ Research Stages

\section{FINDING AND DISCUSSION}

\section{A. Initial Competence of Subjects Teacher Analysis}

Based on the initial measurement of the instrument of subjects teachers, the result shows that all teachers have already used the student-centered learning model. But teachers are not skilled yet in implementing a variated model of student-centered learning. Teachers are also weak in developing learning tools, such as the lesson plan, worksheets, and teaching materials so that in the implementation, the student are less optimal to follow the lesson. The main problem by the teacher in implementing the student-centered learning model is the lack of time availability and the inadequate supporting facilities media.

Percentage of subjects teachers experienced using the environment as a learning resource is quite high at $83.33 \%$. However, only $20 \%$ who have been using mangrove areas as a learning resource.

\section{B. Teachers'Lesson Plan Analysis}

Based on initial analysis result of lesson plan from subjects teacher, it can be seen that:

- Lesson Plan compiled by teachers is general, not developed specifically by environmental conditions observable by student.

- Learning resources outlined in lesson plan is dominantly taken from the student textbook, not integrated yet with the real learning resources.

These results indicate that the teacher is still weak in developing lesson plan in accordance to the learning model/design needed. Generally, teachers' lesson plan are not developed independently by teachers based on basic competency (BC) and indicators but only quoted from the Internet or other sources. $65 \%$ teachers' lesson plan are identical from school to other schools. Whereas Muslich (2008) explains that lesson plan is a design of subjects per unit to be presented by a teacher in the classroom, and a good teacher compile their own lesson plan. Lesson plan may also be used to determine the levels of teachers's ability in their profession performance.

\section{The Integrated Subjects Curriculum Analysis}

Based on the basic competency analysis refers to Permendikbud No. 59 of 2014 about senior high school curriculum, the basic competencies which is relevant to be integrated is grade 10 during odd semester for Biology subject, grade 11 during odd semester for Geography subject, and grade 11 during odd semester for Economics subject. Basic competency of subjects can be seen in Table 1 . 
TABLE I. INTEGRATED BASIC COMPETENCY (BC) TABLE

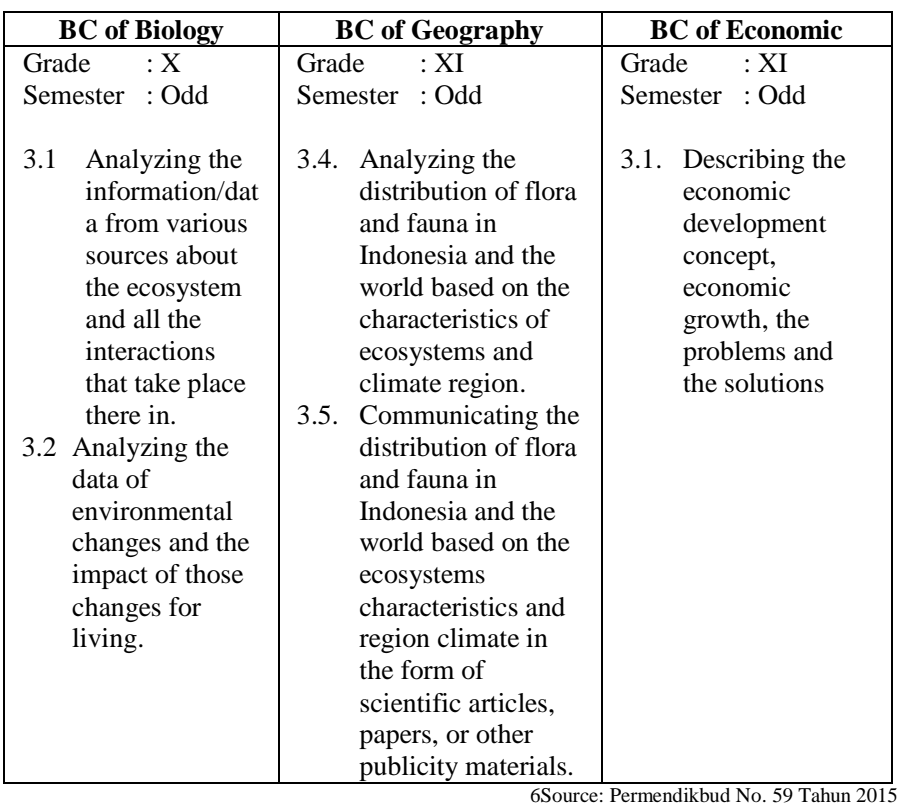

The analysis results above shows that Geography and Economics subjects are able to be integrated in the same grade and semester. While the subjects of Biology is not able to be integrated in the same grade and semester.

\section{Model of Mangrove Ecosystem Utilization as Media and Learning Resources of Environmental Education Design}

Based on the analysis of BC and FGD with teachers samples along with mentoring the teachers to mangrove ecosystems in Tanjung Rejo, it can be obtained an integrated teaching model using the resources and mangrove ecosystem learning media. The model resulted is structured in the form of thematic learning that combines three subjects which are Biology, Geography, and Economics. Based on formulated BC and indicators, the theme specified in the model is "Community-Based Conservation of Mangrove Forest Ecosystem in Tanjung Rejo". Then, this theme is poured into sub-themes that are arranged based on learning indicators.

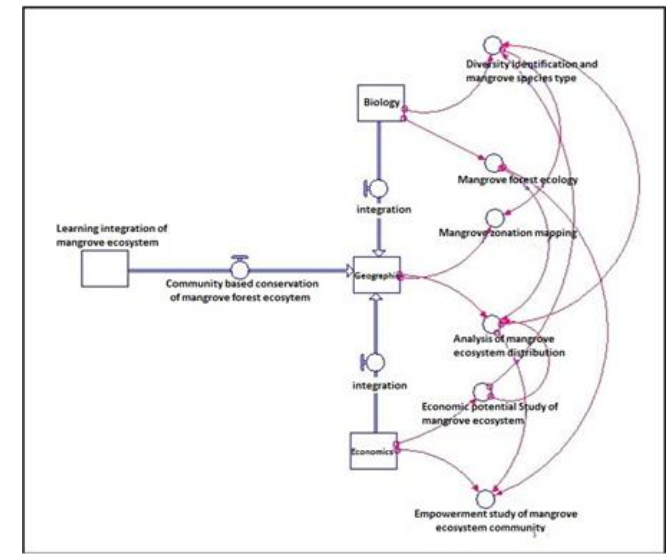

Fig. 2. Integrated Learning Model using Mangrove Ecosystem Learning Source
To achieve the effective and efficient outcomes of environmental education learning, we use several models of learning such as project, problem and discovery based learning. The learning plans are not only able to integrates the subjects, but also integrates those three models of learning and making the learning process more effective and attractive. This is in accordance with the opinion of Adesendjaja (2008), to achieve the goal of environmental education, teacher should start by showing the problems (problem-based learning) encountered in everyday life. In this model, the environmental problems confronted to the students is a damaged mangrove ecosystem which caused not only by natural factors but also human factors.Students are encouraged to look for the root of the problem and then finding the solution. Teachers along with students expand and implement the principles of sustainability and environmental ethics based on the available examples. Environmental education is not the education with memorized topics but contextual topics, so that the environment is the source and the most relevant media. The use of problem, project, and discovery based learning will encourage students to construct knowledge, skills, and attitudes.

On Biology subject, the relevant theme to $\mathrm{BC}$ which chosen is the mangrove planting as an effort to anticipate the impact of environmental change in Tanjung Rejo. Determination of the theme is based on the indicator formulation by BC (Table II). Output of these activities will result student' skills on restoring the quality of the environment by planting mangroves.According to Made et al, (2004) Environmental education is not only the education for students in school that presents the environmental damage caused by human behavior but also environmental education should contain environmental ethics by inviting the the students to stay aware of the environment significance through the knowledge given so as to contribute to the attitude and then generate a wise move for the environment independently. Environmental education targets is placed on the efforts to develop an attitude and rational behavior and being responsible to natural resource management (Sumaatmaja, 2001).

Geography emphasizes on students' competency in identifying mangrove zonation by describing mangrove zonation map based on the field observations result. Subthemes formulated on Geography is mangrove type identification and mangrove zonation mapping in UNIMED Mangrove Management Area in Tanjung Rejo. This theme is strongly relevant to be selected to achieve the basic competencies and learning indicators. According to Murtini (2015), mangrove forests can be used as a learning media especially Geography. So far, school find it difficult to provide a learning media of Geography. In fact, mangrove ecosystems often to be found around the school which is located close to the coast can be used as an effective media to achieve students competencies.

On Economics, students are expected to solve the economic community problems by finding solutions for community alternative income through processing or managing the mangrove ecosystems. According with $\mathrm{BC}$ and selected 
indicators, formulated Sub-themes in the subjects are the calculation of Mangrove Ecosystem Economic Value and community empowerment program around Mangrove ecosystems in Tanjung Rejo. Distribution of indicators, subthemes, output, and Model presented in Table II.

Based on the results of teachers' FGD, integrated learning model of mangrove ecosystem utilization as media and learning resources is potential to be implemented in schools near coastal areas. Integrated model of some subjects allows teachers to mobilize students to the field, because the small number of students involved. The learning process also becomes more focused because the students equipped with knowledge in the classroom before the trip to field as well as a worksheet at the time in the field. indicators, sub-theme, and subjects output

\begin{tabular}{|c|c|c|c|}
\hline Indicators & Sub Theme & Output & Model \\
\hline $\begin{array}{l}\text { 3.1.1 Identifying the } \\
\text { requirement of living } \\
\text { for some kind of } \\
\text { plants found in } \\
\text { mangrove } \\
\text { ecosystems } \\
\text { 3.1.2 Identifying the } \\
\text { interaction that takes } \\
\text { place in the } \\
\text { mangrove } \\
\text { ecosystem. } \\
\text { 3.1.3 Identifying changes } \\
\text { occurred in } \\
\text { mangrove } \\
\text { ecosystems found } \\
\text { around the } \\
\text { neighborhood. } \\
\text { 3.1.4 Analyzing the impact } \\
\text { of the changes that } \\
\text { occur in the } \\
\text { mangrove } \\
\text { ecosystem. } \\
\text { 3.1.5 Taking action to } \\
\text { anticipate } \\
\text { environmental } \\
\text { changes in mangrove } \\
\text { ecosystems }\end{array}$ & $\begin{array}{l}\text { Planting } \\
\text { mangroves as } \\
\text { an effort to } \\
\text { anticipate the } \\
\text { impact of } \\
\text { environmental } \\
\text { change in } \\
\text { Tanjung Rejo. }\end{array}$ & $\begin{array}{l}\text { The result of } \\
\text { mangrove } \\
\text { planting in } \\
\text { locations } \\
\text { experiencing } \\
\text { changes. }\end{array}$ & $\begin{array}{l}\text { Project } \\
\text { Based } \\
\text { Learning }\end{array}$ \\
\hline 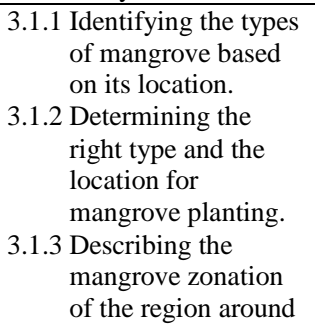 & $\begin{array}{l}\text { Identifying } \\
\text { mangroves } \\
\text { types and } \\
\text { zonation } \\
\text { mapping in } \\
\text { UNIMED } \\
\text { Mangrove } \\
\text { Management } \\
\text { Area, Tanjung } \\
\text { Rejo }\end{array}$ & $\begin{array}{l}\text { identification } \\
\text { report and } \\
\text { mangrove } \\
\text { zonation } \\
\text { mapping in } \\
\text { Tanjung Rejo. }\end{array}$ & $\begin{array}{l}\text { Discovery } \\
\text { based } \\
\text { learning }\end{array}$ \\
\hline 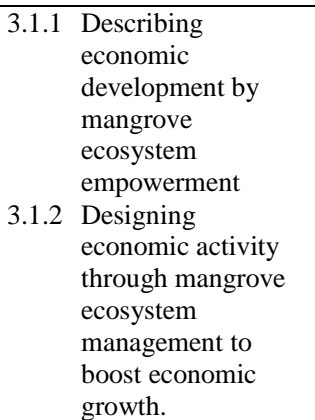 & $\begin{array}{l}\text { Calculating } \\
\text { Mangrove } \\
\text { Ecosystem } \\
\text { Economic } \\
\text { Value and } \\
\text { community } \\
\text { development } \\
\text { programs } \\
\text { around } \\
\text { mangrove } \\
\text { ecosystem in } \\
\text { Tanjung Rejo }\end{array}$ & $\begin{array}{l}\text { The report of } \\
\text { mangrove } \\
\text { economic } \\
\text { value } \\
\text { calculation } \\
\text { result and the } \\
\text { design of } \\
\text { community } \\
\text { empowerment } \\
\text { program. }\end{array}$ & $\begin{array}{l}\text { Problem } \\
\text { based } \\
\text { learning }\end{array}$ \\
\hline
\end{tabular}

\begin{tabular}{|l|l|l|l|}
\hline 3.1 .3 & $\begin{array}{l}\text { Finding economic } \\
\text { problems around } \\
\text { mangrove }\end{array}$ & & \\
ecosystem & & & \\
$3.1 .4 \begin{array}{l}\text { Finding a way to } \\
\text { solve developed } \\
\text { economic problems } \\
\text { around mangrove } \\
\text { ecosystem }\end{array}$ & & & \\
\hline
\end{tabular}

\section{CONCLUSIONS AND SUGGESTIONS}

A. Conclusions of this research are:

- Mangrove ecosystem can be used as a source and learning media of environmental education in the level of senior high school by integrating subjects.

- Integration of subjects for environmental education at senior high school level can be done on the subjects of biology, geography and economics.

- Based on the basic competence structure, only geography and economics subject that can be integrated in the same grade and the same semester that is grade 11 in odd semester, whereas relevant basic competency of biology subject to be integrated can be found on the grade 10 in odd semester.

- Problem, project, and discovery based on learing can be used in Integrated Learning Model by using Mangrove Ecosystem as the learning resources.

B. By the findings and results of the research, we suggest some points below:

- It is necessary to adjust BC distribution based on Permendikbud No. 24 Tahun 2016 so that the integrated BC can be compatible with the latest policy.

- The implemented integration model is largely determined by the support of the school, so there is a need of school budget allocation planned

- It is necessary to test a model to discover the effectiveness of this learning model

- BC alignment among each subjects is necessary to be done due to the number of integrated subjects and similarity in implementation time largely determines the efficiency of this model. 


\section{ACKNOWLEDGMENT}

The authors would like to thank the General Directorate of Higher Education, Ministry of Research, Technology and Higher Education which has provided financial support through University Grant. The author also would like to thank all involved parties in this research include the entire principal and teachers of SMAN 1 Percut Sei Tuan, SMAN 11 Medan and SMAN 7 Medan. Thanks are also submitted to Tanjung Rejo government for supporting this research implementation, especially for the research site preparation. The author also would like to thank all researcher team who had been working well from the beginning until the preparation of this article. Hopefully, this article can provide constructive feedback for the development of environmental education in schools.

\section{REFERENCES}

[1] Adisendjaja, Y.H. 2008," Metodologi Pembelajaran Sains di Sekolah Dasar, Jurusan Pendidikan Biologi”, FPMIPA UPI.

[2] M. Muslich, 2008, "Kurikulum Tingkat Satuan Pendidikan", Bumi Aksara, Jakarta, pp 45.

[3] Murtini S., 2015, "Pengembangan Ekowisata Mangrove Wonorejo Untuk Media Pembelajaran Melalui Pendekatan Berbasis Masyarakat", Jurnal Geografi, Vol 13 No. 1. ISSN 1412-6982. Universitas Negeri Surabaya.

[4] Peraturan Menteri Pendidikan dan Kebudayaan Indonesia No. 59 Tahun 2014 tentang Kompetensi Inti dan Kompetensi Dasar Pelajaran pada Kurikulum 2013 pada Pendidikan Dasar dan Pendidikan Menengah.

[5] Peraturan Menteri Pendidikan dan Kebudayaan Indonesia No, 24 Tahun 2016 tentang Kurikulum 2013 Sekolah Menengah Atas/Madrasah Aliyah.

[6] Sumaatmaja N.2001, "Metode Pengajaran Geografi", Bumi Aksara: Jakarta 